(c) American Dairy Science Association, 2002.

\title{
Fertility of Lactating Dairy Cows Treated with Ovsynch after Presynchronization Injections of $\mathrm{PGF}_{2 \alpha}$ and $\mathrm{GnRH}$
}

\author{
M. W. Peters and J. R. Pursley \\ Department of Animal Science \\ Michigan State University, East Lansing 48824
}

\begin{abstract}
Synchronization of ovulation (Ovsynch) using GnRH and $\mathrm{PGF}_{2 \alpha}$ allows control of follicle growth, corpus luteum regression, and ovulation, but resulting pregnancy rates vary. This study examined whether presynchronization to allow initiation of Ovsynch during diestrus would improve pregnancy rates at timed artificial insemination (AI). Lactating dairy cows $(\mathrm{n}=427), 69$ to $75 \mathrm{~d}$ postpartum, were randomly assigned to two groups by parity. Control cows received Ovsynch (GnRH, d 0; $\mathrm{PGF}_{2 \alpha}$, d 7; GnRH, d 9; timed AI 16 h after second GnRH). Treated cows received presynchronization injections of $\mathrm{PGF}_{2 \alpha}$ and GnRH, 10 and $7 \mathrm{~d}$, respectively, before starting Ovsynch. Pregnancy diagnoses were performed $36 \mathrm{~d}$ after AI. Progesterone $\left(\mathrm{P}_{4}\right)$ concentrations from a subset of cows $(n=84)$ were determined in serum samples collected on d 0,3, and 7 of Ovsynch. Presynchronization increased the percentages of cows with $\geq 1 \mathrm{ng} / \mathrm{ml}$ serum $\mathrm{P}_{4}$ compared with control cows at first injection of $\mathrm{GnRH}$ (d 0; 93 vs. 56\%) and on d 3 (90.7 vs. 51.2\%) during Ovsynch. On day of $\mathrm{PGF}_{2 \alpha}$, d 7 during Ovsynch, percentages of cows with $\geq 1 \mathrm{ng} / \mathrm{ml}$ serum $\mathrm{P}_{4}$ were similar $(95.3 \%$, treated vs. $82.9 \%$, control) but more treated cows had $\geq 2 \mathrm{ng} / \mathrm{ml}$ serum $\mathrm{P}_{4}(95.3$ vs. $63.4 \%)$. However, pregnancy to timed AI was similar between treated (41.5\%) and control cows (38.3\%). Cows with above-average milk production had greater pregnancy rate (45.8 vs. $33.8 \%$ ) compared with lower producing cows. Although presynchrony increased the proportion of cows with luteal function at onset of Ovsynch, pregnancy rate to timed AI was not improved. Cows with above-average milk production had greater fertility at timed AI than herdmates with lower milk production.
\end{abstract}

(Key words: Ovsynch, presynchronization, fertility)

Abbreviation key: Ovsynch = synchronization of ovulation (GnRH, d 0; $\mathrm{PGF}_{2 \alpha}$, d 7; GnRH, d 9; timed

Received October 15, 2001

Accepted March 15, 2002.

Corresponding author: J. R. Pursley; e-mail: pursley@msu.edu.
AI $16 \mathrm{~h}$ after second $\mathrm{GnRH}), \mathbf{P R}=\%$ pregnant to a timed AI.

\section{INTRODUCTION}

Ovsynch [synchronization of ovulation $(\mathrm{GnRH}, \mathrm{d} 0$; $\mathrm{PGF}_{2 \alpha}$, d 7; GnRH, d 9; timed AI $16 \mathrm{~h}$ after second $\mathrm{GnRH})$ ] is a management tool that uses $\mathrm{GnRH}$ and PGF?? to synchronize ovulation, thus allowing control of first and subsequent timed AI in dairy cows (Pursley et al., 1997a). Pregnancy rate to a timed AI (PR) following treatment with Ovsynch is similar to AI after observed estrus ( Burke et al., 1996; Pursley et al., 1997a; Britt and Gaska, 1998; de la Sota et al., 1998; Momcilovic et al., 1998; Pursley et al., 1997b, Stevenson et al., 1999). However, studies indicate that rates of synchronized ovulation following Ovsynch range between 80 and $90 \%$. Thus, improvement of synchronization of ovulation following Ovsynch may increase the percentage of cows that become pregnant. Synchronization of ovulation rate is greatest when Ovsynch is initiated midcycle (Vasconcelos et al., 1999). From those data, it appears that if lactating cows were synchronized into early to midluteal stages of the estrous cycle at the start of Ovsynch, pregnancy rates may be increased. This study tested the effect of initiating Ovsynch in cows presynchronized to the early to midluteal phases of the estrous cycle, compared to initiating Ovsynch at random stages of an estrous cycle.

\section{MATERIALS AND METHODS}

From February to December 1997, lactating Holstein dairy cows $(n=427)$ from a 700-cow commercial dairy farm in Michigan were randomly assigned to two groups on a weekly basis by parity. The control group received the Ovsynch program that consisted of an intramuscular injection of $100 \mu \mathrm{g}$ of GnRH (Cystorelin, Merial Inc., $\mathrm{NJ}$ ), followed in $7 \mathrm{~d}$ with $25 \mathrm{mg}$ of $\mathrm{PGF}_{2 \alpha}$ (Pharmacia \& Upjohn, Kalamazoo, MI), then, $48 \mathrm{hr}$ later, $100 \mu \mathrm{g}$ of GnRH. Treated cows received presynchronization injections of $25 \mathrm{mg}$ of $\mathrm{PGF}_{2 \alpha}, 10 \mathrm{~d}$, and $100 \mu \mathrm{g}$ of $\mathrm{GnRH}$, $7 \mathrm{~d}$, before initiation of Ovsynch (described above) beginning 49 to $55 \mathrm{~d}$ postpartum. All cows received AI 16 


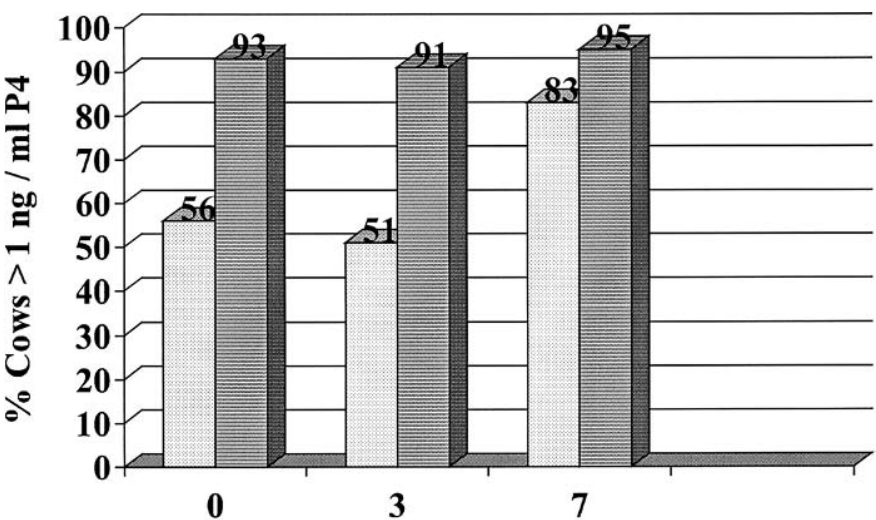

Days from 1st GnRH of Ovsynch

Figure 1. Percentages of cows with $\geq 1 \mathrm{ng} / \mathrm{ml}$ progesterone $\left(\mathrm{P}_{4}\right)$ in serum during Ovsynch in cows presynchronized with $\mathrm{PGF}_{2 \alpha}$ and GnRH, 10 and $7 \mathrm{~d}$, before first GnRH of Ovsynch (treated; striped bars) versus Ovsynch only (control; stippled bars).

$\mathrm{h}$ following the last injection of $\mathrm{GnRH}$. All cows were 69 to $75 \mathrm{~d}$ in lactation at the time of first AI. Laboratory staff administered all injections.

All cows were housed in free stalls, milked twice daily, and received bST beginning at $90 \mathrm{~d}$ postpartum. The herd owner/manager performed all AI. The herd veterinarian diagnosed pregnancy at $36 \mathrm{~d}$ post $\mathrm{AI}$ by rectal examination of the uterus. Progesterone $\left(\mathrm{P}_{4}\right)$ concentrations were determined in a subset of cows $(\mathrm{n}=$ 84) selected randomly within each treatment. Blood samples were collected at the time of the first $\mathrm{GnRH}$ (d 0), $3 \mathrm{~d}$ after the first $\mathrm{GnRH}$, and at the time of $\mathrm{PGF}_{2 \alpha}$ (d 7) of Ovsynch. Serum $\mathrm{P}_{4}$ was quantified by radioimmunoassay $\left(\mathrm{P}_{4}\right.$ Coat-a-count kit, Diagnostic Products Cooperation, Los Angeles, CA). Intra- and interassay coefficients of variation were 5.6 and $9.1 \%$, respectively. Daily milk production nearest to time of AI (DHIA milk weight measurements taken every $2 \mathrm{wk}$ ) was collected to compare PR in cows above- vs. below-mean milk production. Average daily milk production was $34 \mathrm{~kg}$ for first parity, $49.4 \mathrm{~kg}$ for second parity, and $49.9 \mathrm{~kg}$ for third and greater parities.

Pregnancy rate data were analyzed by chi-square using the Proc GENMOD function of SAS. Covariates considered in the analysis of $\mathrm{PR}$ were parity, daily milk production, and interactions of treatment $\times$ parity and daily milk production by parity. Percentages of cows with $\geq 1 \mathrm{ng} / \mathrm{ml}$ of serum $\mathrm{P}_{4}$ or $\geq 2 \mathrm{ng} / \mathrm{ml}$ serum $\mathrm{P}_{4}$ were analyzed by chi-square using the Proc FREQ function of SAS.

\section{RESULTS}

Percentages of cows with a functional corpus luteum are summarized in Figure 1. Among treated cows, a
Table 1. Pregnancy rates (\%) to timed AI in lactating dairy cows following Ovsynch initiated at a random stage of the estrous cycle (control) or during early to midluteal phase of the estrous cycle (treated).

\begin{tabular}{llll}
\hline Parity $^{1}$ & Control & Treated & Total $^{2}$ \\
\hline First & $43.5(\mathrm{n}=69)$ & $52.8(\mathrm{n}=73)$ & $48.2(\mathrm{n}=142)$ \\
Second & $40.0(\mathrm{n}=50)$ & $37.9(\mathrm{n}=58)$ & $38.9(\mathrm{n}=108)$ \\
Third + & $33.3(\mathrm{n}=90)$ & $34.5(\mathrm{n}=87)$ & $33.9(\mathrm{n}=177)$ \\
Total $^{3}$ & $38.3(\mathrm{n}=209)$ & $41.5(\mathrm{~N}=218)$ & $39.9(\mathrm{n}=427)$ \\
\hline
\end{tabular}

${ }^{1}$ No difference in parity $\mathrm{x}$ treatment $(P=0.332)$.

${ }^{2}$ First parity different than third $+(P=0.008)$, others similar $(P>$ $0.14)$.

${ }^{3}$ No difference in treatments $(P=0.87)$.

greater percentage had $\geq 1 \mathrm{ng} / \mathrm{ml}$ serum $\mathrm{P}_{4}$ compared with control cows $(P=0.02)$ at first injection of $\mathrm{GnRH}$ and at $3 \mathrm{~d}$ after the first injection of $\mathrm{GnRH}$ during Ovsynch. At time of $\mathrm{PGF}_{2 \alpha}(\mathrm{d} 7)$ of Ovsynch, percentages of treated and control cows $\geq 1 \mathrm{ng} / \mathrm{ml}^{\text {serum }} \mathrm{P}_{4}(P=0.35)$ were similar. However, in addition to data in Figure 1, the percentage of treated cows with $\geq 2 \mathrm{ng} / \mathrm{ml}$ serum $\mathrm{P}_{4}$ on day of $\mathrm{PGF}_{2 \alpha}$ ?was greater than that of control cows (95.3 vs. $63.4 \% ; P=0.049$ ).

There was no effect of treatment on $\mathrm{PR}(P=0.87$; Table 1). However, PR was greater $(P=0.008)$ for firstversus $\geq$ third-parity cows.

Independent of parity, PR of cows with above-mean milk production were greater $(P<0.025)$ compared with cows with below-mean milk production (Table 2). Firstand third-plus-parity cows with above-mean milk production had greater $(P<0.01)$ PR compared with herdmates with milk production below the mean. However, the mean PR for higher producing second lactation cows were similar and not significantly different (Table 2).

\section{DISCUSSION}

This study was designed to test the effect of starting Ovsynch in midluteal stage of the estrous cycle on fertil-

Table 2. Pregnancy rates (\%) to timed AI of lactating dairy cows following Ovsynch grouped by either above or below mean $(\mu)$ milk production within 2 wk of AI. ${ }^{1}$

\begin{tabular}{llll}
\hline Parity $^{2}$ & $>\mu$ & $<\mu$ & Total \\
\hline First $^{3}$ & $59.7(\mathrm{n}=67)$ & $37.3(\mathrm{n}=75)$ & $48.2(\mathrm{n}=142)$ \\
Second & $35.6(\mathrm{n}=55)$ & $43.4(\mathrm{n}=53)$ & $38.9(\mathrm{n}=108)$ \\
Third $^{4}{ }^{4}$ & $42.4(\mathrm{n}=92)$ & $24.7(\mathrm{n}=85)$ & $33.9(\mathrm{n}=177)$ \\
Total $^{5}$ & $45.8(\mathrm{n}=214)$ & $33.8(\mathrm{n}=213)$ & $39.9(\mathrm{n}=427)$ \\
\hline
\end{tabular}

${ }^{1} \mathrm{DHI}$ data collected every $2 \mathrm{wk}$; all cows inseminated from 69 to $75 \mathrm{~d}$ in lactation.

${ }^{2}$ Treatment data pooled because treatments did not differ.

${ }^{3}$ Different within parity $(P<0.01)$.

${ }^{4}$ Different within parity $(P<0.005)$.

${ }^{5}$ Different between groups $(P<0.025)$. 
ity in lactating dairy cows. Vasconcelos et al. (1999) observed synchronization rates to Ovsynch of $91 \%$ from d 1 to 12 of the estrous cycle compared with $80 \%$ from d 13 to 22 . Improving synchronization rates by 11 percentage points could increase numbers of pregnancies accordingly.

To synchronize cows in the luteal phase of the estrous cycle, treated cows were injected with $\mathrm{PGF}_{2 \alpha} 10 \mathrm{~d}$, and GnRH $7 \mathrm{~d}$, before start of Ovsynch. Cows responding to $\mathrm{PGF}_{2 \alpha}$ with luteal regression may ovulate at various times from injection, depending on the stage of development of the ovulatory follicle at that time. Therefore, cows with a dominant follicle in early stages of a follicle wave $(<10 \mathrm{~mm})$ at time of $\mathrm{PGF}_{2 \alpha}$ would likely have a $\geq 10 \mathrm{~mm}$ antral diameter (Pursley et al., 1996) and would likely have LH receptors (Xu et al., 1995) at the time of the subsequent GnRH injection $3 \mathrm{~d}$ later, and should respond with ovulation. Cows with a large dominant follicle at time of $\mathrm{PGF}_{2 \alpha}$ should have either a follicle that would spontaneously cause an LH surge following $\mathrm{PGF}_{2 \alpha}$ ? or respond to a GnRH-induced LH surge 3 d later (Pursley et al. 1996). The treated group was presynchronized so that cows would likely be in the midluteal stage of the estrous cycle at the onset of Ovsynch. The progesterone data are consistent with this intention. In this subset of cows, the percentage of cows with $\geq 1 \mathrm{ng} / \mathrm{ml}$ serum $\mathrm{P}_{4}$ at the time of first GnRH during Ovsynch and $3 \mathrm{~d}$ later was significantly greater in the treated versus control group. The percentage of cows with greater than $1 \mathrm{ng} / \mathrm{ml}$ serum $\mathrm{P}_{4}$ in the control group at first GnRH was similar to a previous study (Pursley et al., 1997b). Treatment also increased the number of cows with more than $2 \mathrm{ng} / \mathrm{ml}$ serum $\mathrm{P}_{4}$ at the time of the final injection of $\mathrm{PGF}_{2 \alpha}$ during Ovsynch. Theoretically, $66 \%$ of the treated cycling cows should be 5 to $9 \mathrm{~d}$ postestrus. The other one-third would be 10 to $15 \mathrm{~d}$ postestrus. It is likely that $90 \%$ of treated cycling cows would be between 5 to $12 \mathrm{~d}$ postestrus.

The increase in number of cows in the midluteal phase of the estrous cycle did not affect PR to timed AI following treatment. Pregnancy rates in this study were similar for the treated and control groups. Moreira et al. (2001) presynchronized lactating dairy cows with two injections of $\mathrm{PGF}_{2 \alpha} 14 \mathrm{~d}$ apart and $12 \mathrm{~d}$ before Ovsynch. Cycling cows had increased fertility due to presynchronization, but when all cows (including anovulatory cows) were considered, there was no effect of presynchronization on fertility. Cartmill et al. (2001) reported greater fertility due to presynchronization in multiparous but not primiparous cows.

The differences reported due to presynchrony on cycling or multiparous cows in the previously mentioned studies may be the result of a positive influence on the uterine environment due to additional occurrences of estrus before AI. Those studies allowed cycling cows to go through at least one estrus, if not two, whereas in our study, cows were injected $3 \mathrm{~d}$ after $\mathrm{PGF}_{2 \alpha}$ with GnRH. Data from Pursley et al. (1996) indicate approximately one third of cows treated with $\mathrm{PGF}_{2 \alpha}$ at a random stage of the estrous cycle would have a spontaneous LH surge associated with estrus within the first $72 \mathrm{~h}$ following the injection. Thus, it is possible that many cows in our study did not proceed through an additional estrus before Ovsynch. This is likely because an injection of GnRH $72 \mathrm{~h}$ following the $\mathrm{PGF}_{2 \alpha}$ would have prematurely ovulated follicles before a spontaneous estrus and LH surge could occur.

The current data demonstrate that PR decline as parity increases. This trend is consistent with literature reports where synchronization of ovulation was not used (Hillers et al., 1984). However, the effect of parity on PR in this study differs with previous data on synchronization of ovulation (Pursley et al., 1998). In the previous report in which synchronization of ovulation was used, second-parity cows had a higher PR than either first- or $\geq$ third-parity cows. The disparity could be due to a number of factors related to differences in herd management between the two studies.

An interesting aspect of these data is the effect of milk production on fertility. Cows that had above-mean milk production had greater fertility than cows below the mean. This was a high producing herd, and all cows were near peak milk at time of AI (69 to $75 \mathrm{~d}$ in lactation). Previous studies (Spalding et al., 1975; Fonseca et al., 1983; Hillers et al., 1984; Faust et al., 1988) compared fertility of herds at different production levels and found that greater herd milk production negatively affected fertility. There are two possible explanations for the increase in fertility in the cows with above-mean milk production. First, it was likely that cows that produce milk at higher volumes than their herdmates had fewer health problems (feet and legs, mastitis, and periparturient problems such as retained placenta, ketosis, metritis). Badinga et al. (1985) observed that poor-producing cows were less likely to conceive and had a greater number of health-related problems. Secondly, cows with above-average production within a herd are more likely to have double ovulations (Fricke et al., 1998). Cows with multiple ovulations may have a greater chance of conceiving with two or more fertilizable oocytes compared with one.

In summary, presynchronization with PGF?? and GnRH increased the percentage of cows in the midluteal phase of the estrous cycle before starting Ovsynch. However, this did not increase pregnancy rates to timed AI after treatment with Ovsynch. Lactating dairy cows with greater than average milk production also had greater pregnancy rates to timed AI. 


\section{REFERENCES}

Badinga, L., R. J. Collier, C. J. Wilcox, and W. W. Thatcher. 1985. Interrelationships of milk yield, body weight, and reproductive performance. J. Dairy Sci. 68:1828-1831.

Burke, J. M., R. L. de la Sota, C. A. de la Risco, C. R. Staples, E. J. Schmitt, and W. W. Thatcher. 1996. Evaluation of timed insemination using a gonadotropin-releasing hormone agonist in lactating dairy cows. J. Dairy Sci. 79:1385-1393.

Britt, J. S., and J. Gaska. 1998. Comparison of two estrus synchronization programs in a large, confinement-housed dairy herd. JAVMA 212:210-212.

Cartmill, J. A., S. Z. El-Zarkouny, B. A. Hensley, G. C. Lamb, and J. S. Stevenson. 2001. Stage of cycle, incidence, and timing of ovulation, and pregnancy rates in dairy cattle after three timed breeding protocols. J. Dairy Sci. 84:1051-1059.

de la Sota, R. L., J. M. Burke, C. A. Risco, F. Moreira, M. A. DeLorenzo, and W. W. Thatcher. 1998. Evaluation of timed insemination during summer heat stress in lactating dairy cattle. Theriogenology 49:761-770.

Faust, M. A., B. T. McDaniel, O. W. Robison, and J. H. Britt. 1988. Environmental and yield effects on reproduction in primiparous Holsteins. J. Dairy Sci. 71:3092-3099.

Fonseca, F. A., J. H. Britt, B. T. McDaniel, J. C. Wilk, and A. H. Rakes. 1983. Reproductive Traits of Holsteins and Jerseys. Effects of age, milk yield, and clinical abnormalities on involution of cervix and uterus, ovulation, estrous cycles, detection of estrus, conception rate, and days open. J. Dairy Sci. 66:1128-1147.

Fricke, P. M., J. N. Guenther, and M. C. Wiltbank. 1998. Efficacy of decreasing the dose of GnRH used in a protocol for synchronization of ovulation and timed AI in lactating dairy cows. Theriogenology 50:1275-1283.

Hillers, J. K., P. L. Senger, R. L. Darlington, and W. N. Fleming. 1984. Effects of production, season, age of cow, days dry, and days in milk on conception to first service in large commercial dairy herds. J. Dairy Sci. 67:861-867.

Momcilovic, D., L. F. Archibald, A. Walters, T. Tran, D. Kelbert, C. Risco, and W. W. Thatcher. 1998. Reproductive performance of lactating dairy cows treated with gonadotropin-releasing hormone $(\mathrm{GnRH})$ and /or prostaglandin $\mathrm{F}_{2 \alpha}\left(\mathrm{PGF}_{2 \alpha}\right)$ for synchronization of estrus and ovulation. Theriogenology 50:1131-1139.

Moreira F., C. Orlandi, C. A. Risco, R. Mattos, F. Lopes, and W. W. Thatcher. 2001. Effects of presynchronization and bovine somatotropin on pregnancy rates to a timed artificial insemination protocol in lactating dairy cows. J. Dairy Sci. 84:1646-1659.

Pursley, J. R., M. R. Kosorok, and M. C. Wiltbank. 1997a. Reproductive management of lactating dairy cows using synchronization of ovulation. J. Dairy Sci. 80:301-306.

Pursley, J. R., R. W. Silcox, and M. C. Wiltbank. 1998. Effect of time of artificial insemination on pregnancy rates, calving rates, pregnancy loss, and gender ratio after synchronization of ovulation in lactating dairy cows. J. Dairy Sci. 81:2139-2144.

Pursley, J. R., M. C. Wiltbank, J. S. Stevenson, J. S. Ottobre, H. A. Garverick, and L. L. Anderson. 1997b. Pregnancy rates per artificial insemination for cows and heifers inseminated at a synchronized ovulation or synchronized estrus. J. Dairy Sci. 80:295-300.

Spalding, R. W., R. W. Everett, and R. H. Foote. 1975. Fertility in New York inseminated Holstein herds in dairy herd improvement. J. Dairy Sci. 58:718-723.

Stevenson, J. S., Y. Kobayashi, and K. E. Thompson. 1999. Reproductive performance of dairy cows in various programmed breeding systems including Ovsynch and combinations of gonadotropinreleasing hormone and prostaglandin $\mathrm{F}_{2 \alpha}$. J. Dairy Sci. 82:506515 .

Vasconcelos, J. L. M., R. W. Silcox, G. J. M. Rosa, J. R. Pursley, and M. C. Wiltbank. 1999. Synchronization rate, size of the ovulatory follicle, and pregnancy rate after synchronization of ovulation beginning on different days of the estrous cycle in lactating dairy cows. Theriogenology 52:1067-1078.

Xu, Z., H. A. Garverick, G. W. Smith, M. F. Smith, S. A. Hamilton, and R. S. Youngquist. 1995. Expression of follicle-stimulating hormone and luteinizing hormone receptor messenger ribonucleic acids in bovine follicles during the first follicular wave. Biol. Reprod. 53:951-957. 